\title{
Effects of five candidate laxatives derived from Liriope platyphylla on the 5-HT receptor signaling pathway in three cell types present in the transverse colon
}

\author{
JI EUN KIM ${ }^{1}$, EUN KYOUNG KOH ${ }^{1}$, SUNG HWA SONG ${ }^{1}$, JI EUN SUNG ${ }^{1}$, \\ HYUN AH LEE ${ }^{1}$, HONG GU LEE ${ }^{2}$, YOUNG WHAN CHOI ${ }^{3}$ and DAE YOUN HWANG ${ }^{1}$ \\ ${ }^{1}$ Department of Biomaterials Science, College of Natural Resources and Life Science/ \\ Life and Industry Convergence Research Institute, Pusan National University, Miryang, Gyeongsangnam-do 627-706; \\ ${ }^{2}$ Department of Animal Science and Technology, College of Animal Bioscience and Technology, \\ Konkuk University, Seoul 143-701; ${ }^{3}$ Department of Horticultural Bioscience, College of Natural Resources and Life Science, \\ Pusan National University, Miryang, Gyeongsangnam-do 627-706, Republic of Korea
}

Received September 17, 2015; Accepted June 27, 2016

DOI: $10.3892 / \mathrm{mmr} .2016 .5983$

\begin{abstract}
The laxative effects of aqueous extract of Liriope platyphylla (AEtLP) on loperamide (Lop)-induced constipation have been reported; however, the key compounds and the mechanism underlying these effects remain unclear. Therefore, the laxative effects of five candidates derived from L. platyphylla: Diosgenin (DG), 5-hydroxymethylfurfural (5-HMF), adenosine (AD), hydroxypropyl cellulose (HPC) and uridine (UD) were investigated by examining the alteration of $\mathrm{G}$ protein $\alpha(\mathrm{G} \alpha)$ expression, protein kinase $\mathrm{C}(\mathrm{PKC})$ phosphorylation and inositol triphosphate (IP3) concentration levels in the 5-hydroxytryptamine (5-HT; serotonin) receptor signaling pathway. Primary rat intestine smooth muscle cells (pRISMCs), intestinal epithelial cells (IEC)-18 and B35 cells were cotreated with Lop and the five compounds in order to screen the candidates. AEtLP, prucalopride (PCP) and bisacodyl (BS) served as positive controls. In pRISMCs, Ga expression levels were recovered in the majority of candidate-treated groups, whereas PKC phosphorylation recovery was observed only in the DG, 5-HMF and AD treatment groups. In IEC-18 cells, the AD treatment group mimicked the effects of PCP on PKC phosphorylation levels, whereas the DG, 5-HMF, HPC and UD treatment groups mimicked the effects of AEtLP and BS. In B35 cells, a greater upregulation
\end{abstract}

Correspondence to: Professor Dae Youn Hwang, Department of Biomaterials Science, College of Natural Resources and Life Science/Life and Industry Convergence Research Institute, Pusan National University, 50 Cheonghak-ri, Samnangjin-eup, Miryang, Gyeongsangnam-do 627-706, Republic of Korea

E-mail: dyhwang@pusan.ac.kr

Key words: liriope platyphylla, laxative, 5-hydroxymethylfurfural, hydroxypropyl cellulose, uridine, 5-hydroxytryptamine receptor signaling pathway of PKC phosphorylation levels were observed in the UD treatment group compared with the PCP and BS treatment groups, whereas DG, 5-HMF and AD treatment reduced the PKC phosphorylation levels to a greater extent than AEtLP treatment. However, effects similar to AEtLP, PCP and BS on G $\alpha$ expression levels were not detected in any treatment groups in IEC-18 and B35 cells. Furthermore, the level of IP3 was enhanced only in pRISMCs, in which all five candidates were effective, while the greatest concentration was observed in the UD treatment group. In conclusion, the results of the present study suggest that UD may be considered the compound with the greatest laxative activity, which may regulate the 5-HT receptor signaling pathway.

\section{Introduction}

Serotonin (5-hydroxytryptamine; 5-HT) is an important neurotransmitter that is expressed in the gastrointestinal tract, blood platelets and the central nervous system (CNS) (1). However, $>90 \%$ of total body 5 -HT is synthesized, stored and secreted in the enterochromaffin (EC) cells of the intestinal mucosa (2). Following secretion, 5-HT exerts numerous effects on the cells and tissues of the intestine, including activation or relaxation of smooth muscle, epithelial cell secretion, stimulation of sensory neurons and activation of cholinergic neurons (3-5); however, 5-HT is rapidly removed by the serotonin uptake transporter in enterocytes and neurons (6). Furthermore, the various effects of 5-HT may be mediated by $145-\mathrm{HT}$ receptors. Of these, the important $5-\mathrm{HT}_{3}$ and $5-\mathrm{HT}_{4}$ receptors, which are $\mathrm{G}$ protein-coupled receptors expressed by smooth muscle cells, EC cells and myenteric plexus neurons, are considered to be the primary pharmacological targets for gastrointestinal disorder treatment $(7,8)$. This is due to significant alterations in the 5-HT receptor signaling pathway during inflammatory bowel disease, irritable bowel syndrome, postinfectious irritable bowel syndrome and idiopathic constipation (7,9-11). Several safe and effective chemical drugs for the treatment of irritable bowel syndrome with constipation are 
widely used. Agonists of the 5- $\mathrm{HT}_{4}$ receptor, including tegaserod, cisapride and benimidazolones, have been developed to treat slow transit through the promotion of gastric emptying and alleviation of chronic constipation, whereas $5-\mathrm{HT}_{3}$ receptor antagonists, including alosetron and cilansetron, have been used to treat nausea, emesis and diarrhea through decreased visceral sensitivity and postprandial motility (12-14). However, investigators are seeking novel drugs originating from natural products due to the pharmacological and economical limitations of chemical drugs, including toxicity, side effects and high cost.

Various herbal plants exhibiting laxative activity have been investigated as possible novel therapeutic strategies for the treatment of constipation to circumvent the side effects of chemical drugs (15-17). Significant improvements in intestinal motility, stool number, stool water content and distal colon thickness have previously been observed in constipated animals treated with Aloe ferox Mill (18), Aquilaria sinensis/Aquilaria crasna (15), and Ficus carica $(16,19)$. Treatment with aqueous extract of Liriope platyphylla (AEtLP) has also been shown to effectively improve loperamide (Lop)-induced constipation in Sprague Dawley (SD) rats via increased stool and urine excretion, villus length, crypt layer, muscle thickness and lipid droplet secretion (19). This previous study provided the first evidence that the laxative effects of AEtLP may be closely correlated with the muscarinic acetylcholine receptors signaling pathway (19). However, the primary components responsible for laxative activity and the underlying mechanisms remain to be elucidated.

The present study was conducted to investigate the effects of five laxative candidates [diosgenin (DG), 5-hydroxymethylfurfural (5-HMF), adenosine (AD), hydroxypropyl cellulose (HPC) and uridine (UD)] derived from L. platyphylla on the 5-HT receptor downstream signaling pathway in primary rat intestine smooth muscle cells (pRISMCs), intestinal epithelial cells (IEC)-18 and B35 cells. The results of the present study provide evidence that UD may be a potential candidate for 5-HT receptor signaling pathway regulation.

\section{Materials and methods}

Care and use of laboratory animals. The animal protocol used in the present study was reviewed and approved based on ethical procedures and scientific care by the Pusan National University-Institutional Animal Care and Use Committee (Miryang, South Korea; Approval Number PNU-2014-0572). Adult male and female SD rats (age, 8 weeks; weight, 220-250 g; $\mathrm{n}=6$ ) purchased from Samtako Inc. (Osan, South Korea) were handled in the Pusan National University-Laboratory Animal Resources Center accredited by the Ministry of Food and Drug Safety (Osong, South Korea; Accredited Unit Number-000231) and the Association for Assessment and Accreditation of Laboratory Animal Care International (Frederick, MD, USA; Accredited Unit Number; 001525). Animals were provided with ad libitum access to water and a standard irradiated chow diet (Samtako Inc.) consisting of moisture (12.5\%), crude protein $(25.43 \%)$, crude fat $(6.06 \%)$, crude fiber (3.9\%), crude ash $(5.31 \%)$, calcium $(1.14 \%)$ and phosphorus $(0.99 \%)$, throughout the feeding study. During the experiment, all rats were maintained in specific pathogen-free conditions under a 12-h light/dark cycle at $23 \pm 2^{\circ} \mathrm{C}$ and $50 \pm 10 \%$ relative humidity. Infant rats (age, 3 days) were obtained by breeding male and female SD rats.

Preparation of pRISMCs. pRISMCs were prepared as previously described (20), with slight modifications to the treatment duration and enzyme concentrations. The cells were collected from infant rather than adult rats, since the infant tissue had greater differentiation and proliferation abilities, similar to those of the fetus $(20,21)$. Briefly, 3-day-old rats $(n=5)$ were euthanized using a $\mathrm{CO}_{2}$ chamber, following which their intestines were collected (Fig. 1A). The small intestines from $1 \mathrm{~cm}$ below the pyloric ring to the cecum were removed and opened along the mesenteric border (Fig. 1B). Luminal contents were then removed by washing with calcium-free Hank's solution [5.36 mmol/l KCl, $125 \mathrm{mmol} / 1 \mathrm{NaCl}, 0.34 \mathrm{mmol} / \mathrm{l} \mathrm{NaOH}$, $0.44 \mathrm{mmol} / 1 \mathrm{Na}_{2} \mathrm{HCO}_{3}, 10 \mathrm{mmol} / \mathrm{l}$ glucose, $2.9 \mathrm{mmol} / \mathrm{l}$ sucrose and $11 \mathrm{mmol} / 1$ HEPES ( $\mathrm{pH}$ 7.4)]. Tissues were pinned to the base of a silicon-covered Petri dish, following which the mucosa layers were removed by sharp dissection (Fig. 1C and D). Small tissue strips of the intestinal muscle (consisting of circular and longitudinal muscles) were incubated in digestion solution $[1 \mathrm{mg} / \mathrm{ml}$ collagenase (catalog no. 4174; Worthington Biochemical Corporation, Lakewood, NJ, USA), $0.5 \mathrm{mg} / \mathrm{ml}$ trypsin inhibitor (catalog no. T9128; Sigma-Aldrich, St. Louis, MO, USA), $1 \mathrm{mg} / \mathrm{ml}$ bovine serum albumin (catalog no. A2153; Sigma-Aldrich)] at $37^{\circ} \mathrm{C}$ for $30 \mathrm{~min}$ (Fig. 1E). Following centrifugation at $1,000 \mathrm{x} \mathrm{g}$, $23-25^{\circ} \mathrm{C}$ for $10 \mathrm{~min}$, pRISMCs were seeded into culture plates containing Dulbecco's modified Eagle's medium (DMEM; HyClone; GE Healthcare Life Sciences, Logan, UT, USA) and grown in a $37^{\circ} \mathrm{C}$ humidified incubator under $5 \% \mathrm{CO}_{2}$ (Fig. $1 \mathrm{~F}$ ). pRISMCs were limited to passage 5 for cell culture studies to avoid significant genetic drift.

Contamination of the pRISMC population was assessed by reverse transcription-polymerase chain reaction (RT-PCR) analysis, performed as described previously (22) with slight modifications to the total RNA concentration. Total RNA was purified by removing media from pRISMCs and homogenizing the cells in RNAzol (Tel-Test Inc., Friendswood, TX, USA). The isolated RNA was then measured by UV spectroscopy and $5 \mu \mathrm{g}$ total RNA was used to synthesize cDNA. Oligo dT primers (500 ng; Invitrogen; Thermo Fisher Scientific, Inc., Waltham, MA, USA) were annealed at $70^{\circ} \mathrm{C}$ for $10 \mathrm{~min}$, and deoxyadenosine, deoxycytidine, deoxyguanosine and deoxythymidine triphosphates were added with 200 units of $200 \mathrm{U} / \mu 1$ Superscript II reverse transcriptase (catalog no. 18064-014; Invitrogen; Thermo Fisher Scientific, Inc.). Subsequently, 10 pmol sense and antisense primers (Macrogen, Inc., Seoul, Korea) were added, and the reaction mixture was subjected to 25 cycles of amplification using a PCR Core kit (Roche Diagnostics, Basel, Switzerland). Amplification was conducted in a Perkin-Elmer Thermal Cycler using the following cycling conditions: An initial denaturation step of $7 \mathrm{~min}$ at $94^{\circ} \mathrm{C}$ was performed, followed by 25 cycles of $30 \mathrm{sec}$ at $94^{\circ} \mathrm{C}, 30 \mathrm{sec}$ at $62^{\circ} \mathrm{C}$ and $45 \mathrm{sec}$ at $72^{\circ} \mathrm{C}$, and a final extension step of $7 \mathrm{~min}$ at $72^{\circ} \mathrm{C}$. The primer sequences for target gene expression identification were as follows: Sense, 5'-GCCTG CCGAA ATGTA TGACG-3' and antisense, 5'-GGTTC TCTGG GTTGG GGT-3' for c-kit (an interstitial cell of cajal 
marker); sense, 5'-TACTT CATGA AGCAG ACCAT CG-3' and antisense, 5'-CTGCA GCAGA GAGTC CTCTG AACTG-3' for protein gene product 9.5 (PGP9.5; a neuronal cell marker); sense, 5'-GCAAC TGAGC AATGA GCTGG TCAC-3' and antisense, 5'-CTGCT CCTTG TACTG CTCCA CCATC-3' for myosin, heavy chain 11 (Myh11; a myosin-smooth muscle cell marker); and sense, 5'-TGG AAT CCT GTG GCA TCC ATG AAA C-3' and antisense, 5'-TAA AAC GCA GCT CAG TAA CAG TCC G-3' for $\beta$-actin. The experiment was repeated three times and all samples were analyzed in triplicate. The final PCR products were separated on a $1.2 \%$ agarose gel and were visualized by ethidium bromide staining. Of the three markers, only high expression levels of Myh11 were detected (Fig. 1G).

Preparation of five candidates. As listed in Table I, five laxative candidates (DG, 5-HMF, AD, HPC, UD) were selected from various compounds and substances derived from the roots of L. platyphylla as previously described (23-30). Candidates were selected according to the following criteria: i) Compounds and substances associated with the metabolic function of the intestines; ii) compounds and substances that stimulate intestinal cells; and iii) compounds and substances that have similar structures to laxative materials reported in previous studies (23-30). The root samples of L. platyphylla were collected from plantations in the Miryang area of South Korea between 2009 and 2010, and were identified by Dr Cha Shin Woo at the Herbal Crop Research Division, National Institute of Horticultural \& Herbal Science (Eumseong, South Korea). Voucher specimens (ref. WPC-11-010) were deposited at the Functional Materials Bank of the Wellbeing RIS Center of Pusan National University. DG, 5-HMF, AD, HPC and UD were purchased from Sigma-Aldrich, whereas two commercial drugs, prucalopride (PCP; Resolor) and bisacodyl mixture (BS; Bicogreen), were acquired from Janssen Korea Ltd. (Seoul, South Korea) and Kolon Pharmaceuticals, Inc. (Gwachon, South Korea), respectively.

The roots of L. platyphylla were weighed and then ground with a Hanil mixer (HMF-3100S; Hanil Electronics Co., Ltd., Seoul, South Korea).L.platyphylla powder ( 1 g) was sonicated in $10 \mathrm{ml}$ distilled water for $1 \mathrm{~h}$, followed by centrifugation for $10 \mathrm{~min}$ at $2,500 \mathrm{x} \mathrm{g}, 23-25^{\circ} \mathrm{C}$. The supernatant was transferred to a $30 \mathrm{ml}$ volumetric flask. This procedure was repeated three times and respective supernatants were combined. The final volume was adjusted to $30 \mathrm{ml}$ with distilled water. Prior to use all samples were filtered through $0.45-\mu \mathrm{m}$ nylon membrane filters.

High performance liquid chromatography (HPLC) analysis. The one-dimensional HPLC system (Agilent 1100; Agilent Technologies, Inc., Santa Clara, CA, USA) consisted of a quaternary pump, an auto-sampler, a degasser, an automatic thermostatic column compartment and a diode array detector. Chromatographic conditions for AD, HPC and UD analysis were as follows: A Phenomenex Luna C18 column (150x4.6 mm internal diameter; $5 \mathrm{~mm}$ particle size; Phenomenex, Torrance, CA, USA) was used; gradient elution was performed with (A) $0.025 \%$ formic acid in water and (B) acetonitrile (0-10 min, 0-5\% B; 10-20 min, 5\% B; 20-30 min, 5-15\% B; 30-40 min, $15 \% \mathrm{~B} ; 40-50 \mathrm{~min}, 15-100 \% \mathrm{~B} ; 50-55 \mathrm{~min}, 100 \% \mathrm{~B}$; and
Table I. Candidates derived from L. platyphylla to investigate the laxative effects on the 5-hydroxytryptamine receptor signaling pathway.

\begin{tabular}{ll} 
Candidate & \multicolumn{1}{c}{ Medicinal effect (ref.) } \\
\hline Diosgenin & $\begin{array}{l}\text { Anti-diabetic effect (21) } \\
\text { Anti-allergic effect (22) } \\
\text { Anti-inflammatory effect (23) } \\
\text { 5-Hydroxymethylfurfural }\end{array}$ \\
Adenosine & $\begin{array}{l}\text { Improves hemolytic disease (25) } \\
\text { Improves hematopoietic } \\
\text { malignancy (26) }\end{array}$ \\
Hydroxypropyl cellulose & $\begin{array}{l}\text { Improves cholesterol } \\
\text { concentration (27) }\end{array}$ \\
Uridine & Sterol-lowering effect (28) \\
\hline
\end{tabular}

55-60 $\mathrm{min}, 100-0 \% \mathrm{~B}$ ); the flow rate was $0.5 \mathrm{ml} / \mathrm{min}$; and the column temperature was $30^{\circ} \mathrm{C}$. For DD and 5-HMF analysis, gradient elution was performed with (A) deionized water and (B) acetonitrile (0-25 min, 30-90\% B; and 25-40 min, 90\% B). A flow rate of $1.0 \mathrm{ml} / \mathrm{min}$ was used. The flow rate and pressure were maintained at $1.53 \mathrm{ml} / \mathrm{min}$ and $35 \pm 2 \mathrm{psi}$, respectively. The wavelength was set at $254 \mathrm{~nm}$ and the output signal of the detector was recorded using Clarity ${ }^{\mathrm{TM}}$ Chromatography Software version 6.0 (DataApex, Prague, Czech Republic).

Determination of $U D$ and $A D$ concentration. Individual stock solutions of UD and AD were prepared at a concentration of $0.5 \mathrm{mg} \mathrm{ml}^{-1}$ in distilled water. The quantification was performed using seven levels of external standards. The ranges obtained were $0.5-50 \mu \mathrm{g} \mathrm{ml}^{-1}$ depending on the concentration of each stock solution. Table II presents the calibration data and calculated limit of detection. The linearity of the method was evaluated by analyzing a series of standard UD and AD. Each of the six working UD and AD solutions (10 $\mu \mathrm{l})$ containing 0.5-50 $\mu \mathrm{g}$ was subjected to HPLC. The elution was performed as previously described and standard calibration curves were obtained by plotting the concentration of UD and AD vs. peak area. The calibration range was chosen to reflect UD and AD concentrations in watermelon samples. The range included concentrations from the lower limit of detection (LOD) and limit of quantification (LOQ).

Treatment schedule. IEC-18, an epithelial cell line derived from the ileum of rat intestines, and B35, a neuroblastoma cell line derived from tumors of the neonatal rat CNS, were purchased from the Korean Cell Line Bank (Seoul, South Korea). The cells were cultured in a humidified incubator at $37^{\circ} \mathrm{C}$ under $5 \% \mathrm{CO}_{2}$ in Eagle's minimal essential medium with Earle's balanced salt solution (MEM/EBSS; catalog no. SH30024.01; Thermo Fisher Scientific, Inc.) supplemented with $10 \%$ fetal bovine serum (Gibco; Thermo Fisher Scientific, Inc.), 2 mM glutamine, $100 \mathrm{U} / \mathrm{ml}$ penicillin and $100 \mu \mathrm{g} / \mathrm{ml}$ streptomycin.

To prepare the total cell lysate, the three cell types were seeded at a density of $1 \times 10^{7}$ cells $/ 10 \mathrm{ml}$ in $100-\mathrm{mm}$ diameter culture dishes, and cultured with $20 \mu \mathrm{M}$ Lop (Sigma-Aldrich) 

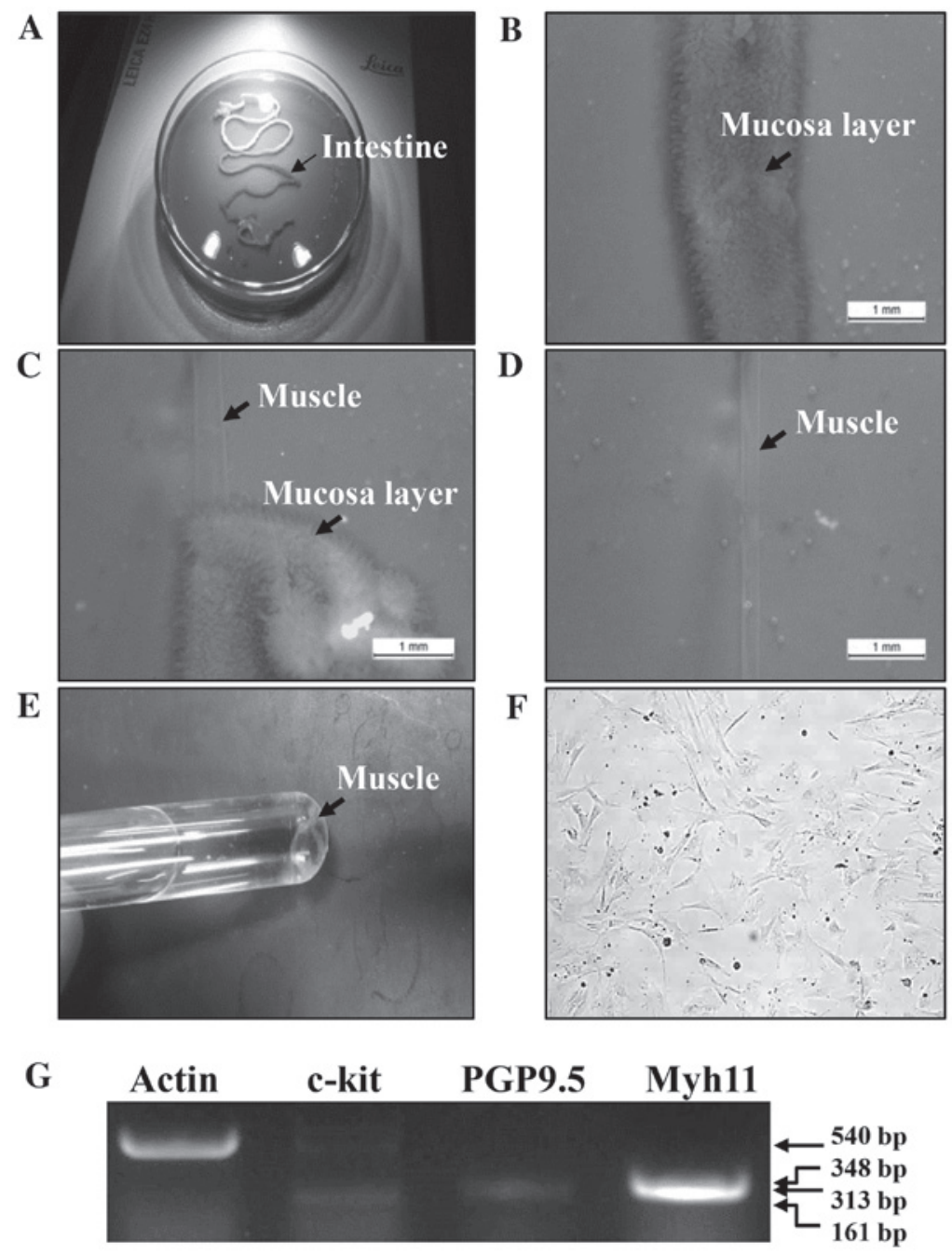

Figure 1. Preparation of pRISMCs from infant SD rats. (A) Intestine samples were collected from 3-day-old SD rats. (B) Small intestines were opened along the mesenteric border. (C) Mucosa layers were removed by sharp dissection, (D) leaving intestinal muscle. (E) Small tissue strips of the intestine muscle were harvested and then incubated in digestion solution with collagenase type 1. (F) pRISMCs were seeded into cell culture plates and their morphology was observed under an inverted microscope. Magnification, x200. (G) RT-PCR analysis of pRISMCs. The mRNA expression levels of c-kit, PGP9.5 and Myh11 were examined by RT-PCR in pRISMCs collected from infant intestines. pRISMCs, primary rat intestine smooth muscle cells; SD, Sprague Dawley; RT-PCR, reverse transcription-polymerase chain reaction; PGP9.5, protein gene product 9.5; Myh11, myosin, heavy chain 11.

for $12 \mathrm{~h}$ in a $37^{\circ} \mathrm{C}$ incubator. The Lop-containing culture media was then removed, and cells of each group were treated with $25 \mu \mathrm{M}$ DG, $100 \mu \mathrm{M}$ 5-HMF, $100 \mu \mathrm{M}$ AD, $100 \mu \mathrm{M} \mathrm{UD}$, $100 \mu \mathrm{g} / \mathrm{ml}$ of HPC, $100 \mu \mathrm{g} / \mathrm{ml}$ of AEtLP, $1 \mu \mathrm{g} / \mathrm{ml}$ of PCP or $5 \mu \mathrm{g} / \mathrm{ml} \mathrm{BS}$, whereas the vehicle control group received the same volume of $\mathrm{dH}_{2} \mathrm{O}$, for a further $12 \mathrm{~h}$. The untreated group did not receive any treatment during the experimental period. Subsequently, cells harvested from 100-mm diameter culture dishes were homogenized with $1 \%$ Nonidet P-40 in $150 \mathrm{mM} \mathrm{NaCl}, 10 \mathrm{mM}$ Tris $\mathrm{HCl}(\mathrm{pH} 7.5)$ and $1 \mathrm{mM}$ EDTA, then supplemented with a protein inhibitor mixture (Roche Diagnostics, Basel, Switzerland). Lysates were stored at $-70^{\circ} \mathrm{C}$ until use.

Western blot analysis. Total proteins were extracted from pRISMC, IEC-18 and B35 cells treated with the five candidates using Pro-Prep Protein Extraction Solution (Intron Biotechnology, Inc., Seongnam, Korea). Following centrifugation at $11,000 \mathrm{xg}, 4^{\circ} \mathrm{C}$ for $5 \mathrm{~min}$, the protein concentrations were determined using a SMART ${ }^{\mathrm{TM}}$ Bicinchoninic Acid Protein assay kit (Thermo Fisher Scientific, Inc.). Proteins (30 $\mu \mathrm{g})$ were separated by $4-20 \%$ sodium dodecyl sulfate-polyacrylamide gel electrophoresis for $3 \mathrm{~h}$, following which the resolved proteins were transferred to nitrocellulose membranes for $2 \mathrm{~h}$ at $40 \mathrm{~V}$. Membranes were blocked with $10 \%$ skim milk in phosphate-buffered saline (PBS) for $1 \mathrm{~h}$, and incubated with the primary antibodies, rabbit anti-G protein a subunit (1:1,000; catalog no. ab58916; Ga; Abcam, Cambridge, UK), rabbit anti-protein kinase C (1:1,000; catalog no. 2056; PKC; Cell Signaling Technology Inc., Danvers, MA, USA), rabbit anti-phosphorylated PKC (1:1,000; catalog no. 9371; p-PKC; Cell Signaling Technology Inc.) and rabbit anti- $\beta$-actin (1:2,000; catalog no. A2066; Sigma-Aldrich) overnight at $4^{\circ} \mathrm{C}$. Membranes were washed with washing buffer $(137 \mathrm{mM} \mathrm{NaCl}$, $2.7 \mathrm{mM} \mathrm{KCl}, 10 \mathrm{mM} \mathrm{Na}_{2} \mathrm{HPO}_{4}, 2 \mathrm{mM} \mathrm{KH}_{2} \mathrm{PO}_{4}$ and $0.05 \%$ Tween 20) and incubated with horseradish peroxidase-conjugated goat anti-rabbit IgG (1:1,000; catalog no. 81-6120; Thermo Fisher Scientific, Inc.) at room temperature for $2 \mathrm{~h}$. 
Structural formula

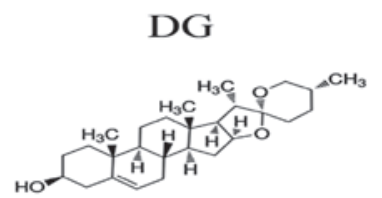

5-HMF<smiles>O=Cc1ccc(CO)o1</smiles>

HPC

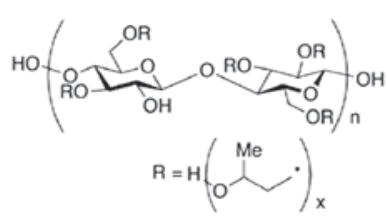<smiles>O=c1ccn(C2OC(CO)C(O)C(O)C2O)c(=O)[nH]1</smiles>

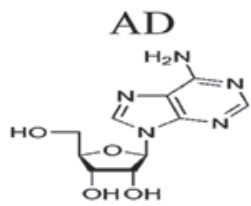

Chromatogram
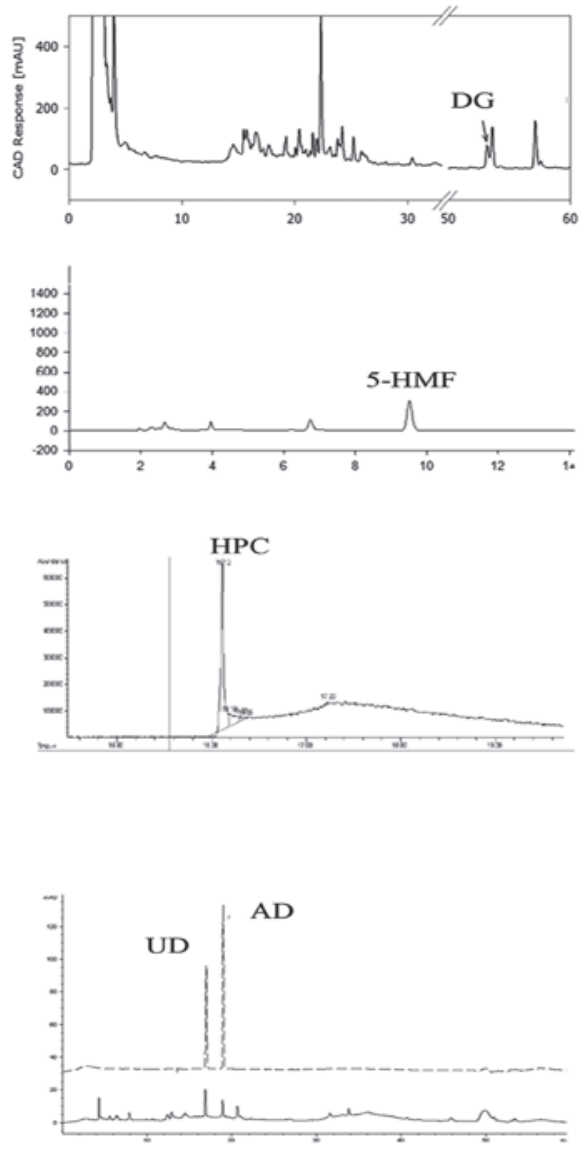

Figure 2. Structural formula and chromatograms of the five candidates. Chromatograms of the five candidates were obtained by performing high performance liquid chromatography on the extracts of L. platyphylla. The peaks corresponding to each candidate are labeled. Peak height/area reflect the concentration of the candidates in the sample. DG, diosgenin; 5-HMF, 5-hydroxymethylfurfural; AD, adenosine; HPC, hydroxypropyl cellulose; UD, uridine.

Finally, the blots were developed using Chemiluminescence Reagent Plus kit (Pfizer Inc., Gladstone, NJ, USA). The signal image for each protein was acquired using the digital camera (1.92 MP resolution) of the FluorChem ${ }^{\circledR}$ FC2 Imaging system (Alpha Innotech Corporation, San Leandro, CA, USA) and their density was semi-quantified using AlphaView Program version 3.2.2 (Cell Biosciences, Inc., Santa Clara, CA). Total protein levels of three samples from each group were analyzed in three separate western blot analyses.

Analysis of inositol triphosphate (IP3) concentration. The concentration of IP3 in the three cell types was determined using a rat IP3 enzyme-linked immunosorbent assay kit (Cusabio Biotech Co., Ltd., Wuhan, China) according to the manufacturer's protocol. Following treatment with the five candidates, cells $\left(2 \times 10^{7}\right)$ were harvested and homogenized in ice-cold phosphate-buffered saline $(\mathrm{pH}$ 7.2-7.4) with a glass homogenizer (Sigma-Aldrich). Total cell lysates were prepared with a glass homogenizer and PBS, and centrifuged at $5,000 \mathrm{x} \mathrm{g}$ for $5 \mathrm{~min}$ at room temperature, following which the supernatant was collected for analysis. An anti-IP3 detection antibody was added and samples were incubated at $37^{\circ} \mathrm{C}$ for $60 \mathrm{~min}$, followed by the addition of substrate solution for $15 \mathrm{~min}$ at $37^{\circ} \mathrm{C}$. The reaction was terminated by the addition of stop solution and the plates were read at an absorbance of $450 \mathrm{~nm}$ using a VersaMax Plate reader (Molecular Devices, LLC, Sunnyvale, CA, USA).

Statistical analysis. Statistical analyses were performed using SPSS software version 10.10 (SPSS, Inc. Chicago, IL, USA). One-way analysis of variance, followed by Tukey's post hoc test, was performed to identify significant differences between the vehicle and candidate-treated groups, or between the untreated and Lop-treated groups. All values are presented as the mean \pm standard deviation. $\mathrm{P}<0.05$ was considered to indicate a statistically significant difference.

\section{Results}

Identification of five candidates in L. platyphylla. The presence of the five candidates in L. platyphylla was confirmed using HPLC analysis. As presented in Fig. 2, DG, 5-HMF, AD, HPC and UD were detected in the HPLC chromatogram of L. platyphylla under the optimal conditions, although their 
A

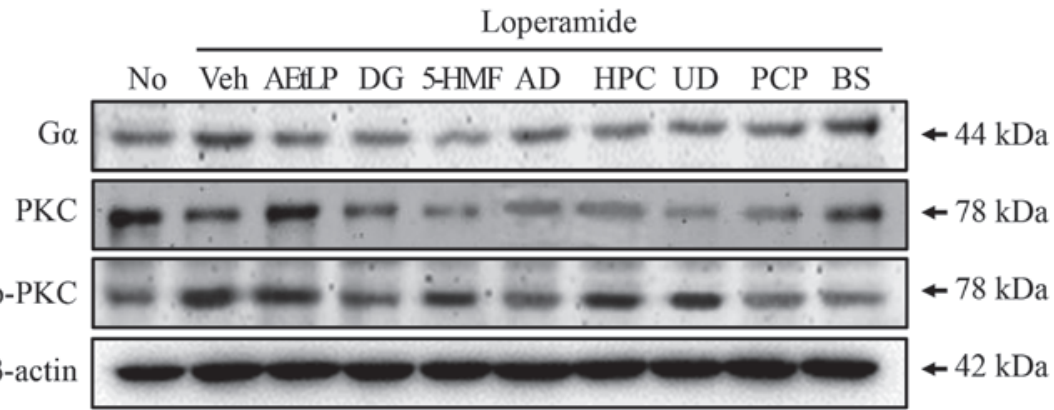

B

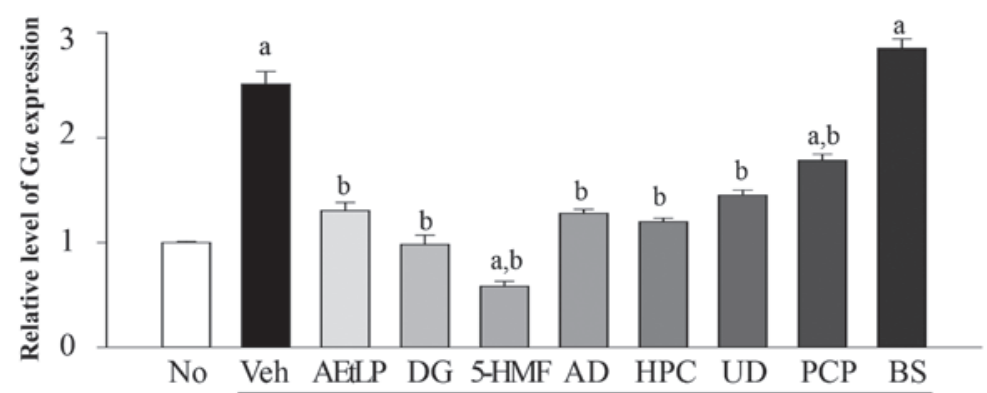

C

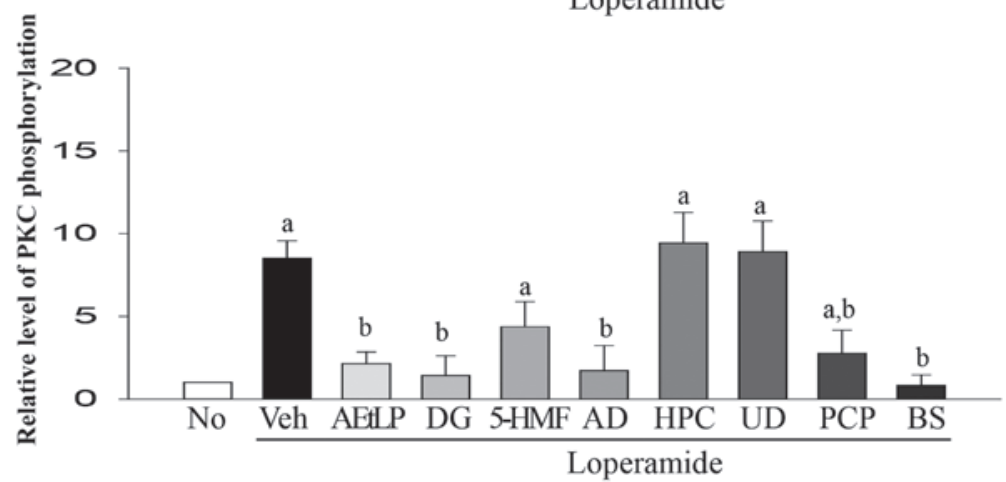

Figure 3. Alteration of Ga expression and PKC phosphorylation levels in pRISMC. (A) Western blot analysis was performed on total protein extracted from Lop-pretreated pRISMCs following treatment with the five laxative candidates. The levels of G $\alpha$ expression and PKC phosphorylation were detected using specific antibodies. The $\beta$-actin protein expression level served as an endogenous control. The band intensity of the three proteins was determined by densitometry and the level of (B) G $\alpha$ expression and (C) PKC phosphorylation was calculated relative to $\beta$-actin. Data are presented as the mean \pm standard deviation of three replicates. ${ }^{a} \mathrm{P}<0.05$ vs. untreated group; ${ }^{b} \mathrm{P}<0.05$ vs. Lop+vehicle treatment group. G $\alpha, \mathrm{G}$ protein $\alpha$; PKC, protein kinase $\mathrm{C}$; pRISMCs, primary rat intestine smooth muscle cells; Lop, loperamide; No, untreated; Veh, vehicle; AEtLP, aqueous extract of Liriope platyphylla; DG, diosgenin; 5-HMF, 5-hydroxymethylfurfural; AD, adenosine; HPC, hydroxypropyl cellulose; UD, uridine; PCP, prucalopride; BS, bisacodyl.

concentrations and detection times varied. Of the candidates, HPC had the highest peak, and UD the lowest.

Effects of the five laxative candidates on the 5-HT receptor signaling pathway in intestinal muscle cells. To examine the effects of the five laxative candidates on the 5-HT receptor signaling pathway, the expression levels of $\mathrm{G} \alpha$ and the phosphorylation levels of PKC were measured in Lop-pretreated pRISMCs following treatment with the five laxative candidates (Fig. 3A). The protein expression levels of $\mathrm{G} \alpha$ were $140 \%$ greater in the Lop+vehicle group compared with the untreated group. However, G $\alpha$ protein expression levels decreased to varying extents in the majority of treatment groups. Similar levels were detected in the Lop+AEtLP and Lop+PCP treatment groups, which were used as positive controls, whereas the lowest expression levels of $\mathrm{G} \alpha$ were measured in the Lop+5-HMF treatment group (Fig. 3B). The phosphorylation levels of PKC differed from
G $\alpha$ expression levels. Phosphorylation levels were $430 \%$ greater in the Lop+vehicle treatment group compared with the untreated group. However, levels were rapidly recovered in the positive control Lop+AEtLP, Lop+PCP and Lop+BS treatment groups. Furthermore, a marked decrease in $\mathrm{PKC}$ phosphorylation was observed in the Lop+DG and Lop+AD treatment groups, whereas partial recovery was observed in the Lop+5-HMF treatment group. However, the level of PKC protein phosphorylation was not decreased in the Lop+HPC and Lop+UD treatment groups (Fig. 3C). Taken together, these results suggest that DG, 5-HMF and AD may stimulate the complete or partial recovery of $\mathrm{G} \alpha$ expression and PKC phosphorylation levels induced by Lop treatment in smooth muscle cells of rat intestine.

Effects of the five laxative candidates on the 5-HT receptor signaling pathway in epithelial cells. To determine whether the effect on the 5-HT receptor signaling pathway observed in 


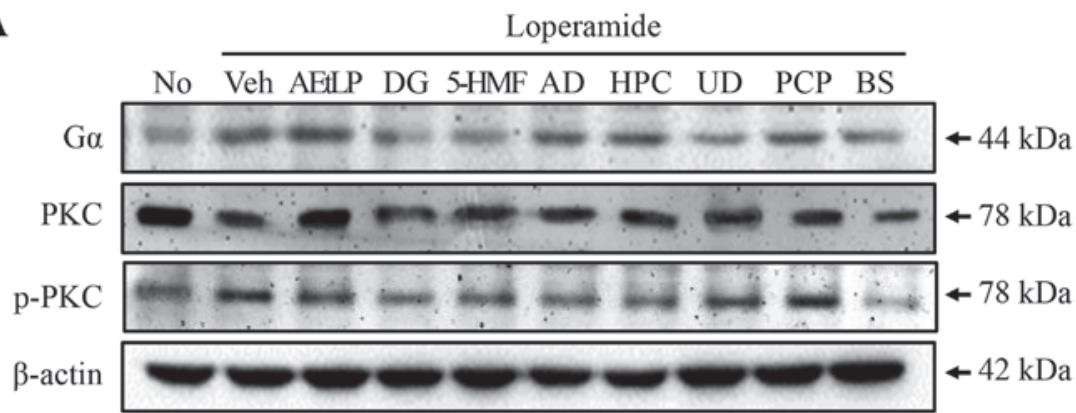

\section{B}

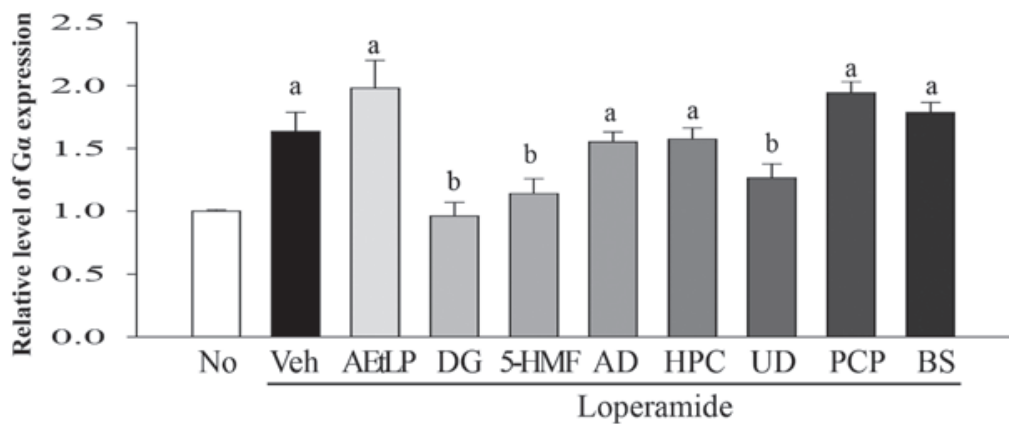

C

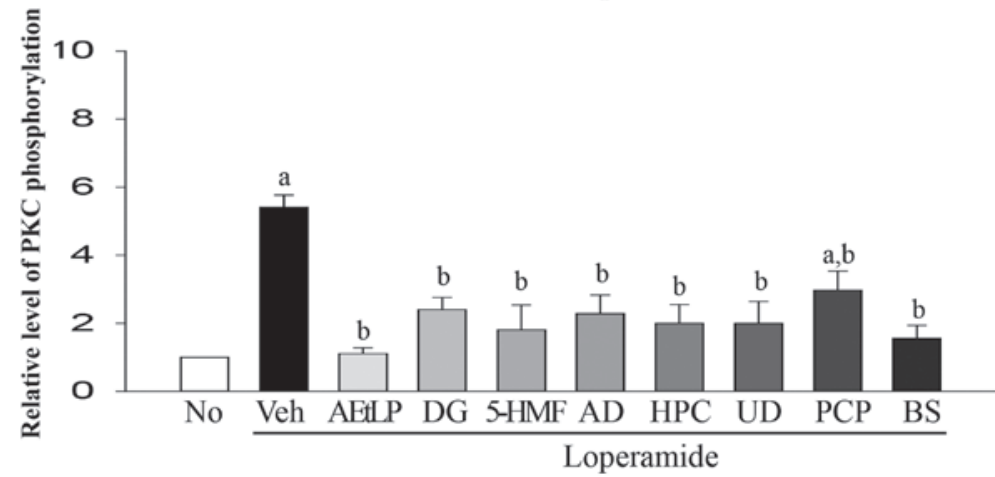

Figure 4. Alteration of G $\alpha$ expression and PKC phosphorylation levels in IEC-18 cells. (A) Western blot analysis was performed on total protein extracted from the Lop-pretreated IEC-18 cells following treatment with the five laxative candidates. The levels of Ga expression and PKC phosphorylation were detected with specific antibodies. The $\beta$-actin protein expression level served as an endogenous control. The band intensity of the three proteins was determined by densitometry and the level of (B) G $\alpha$ expression and (C) PKC phosphorylation was calculated relative to $\beta$-actin. Data are presented as the mean \pm standard deviation of three replicates. ${ }^{\mathrm{P}} \mathrm{P}<0.05$ vs. untreated group; ${ }^{\mathrm{b}} \mathrm{P}<0.05$ vs. Lop+vehicle treatment group. G $\alpha, \mathrm{G}$ protein $\alpha$; PKC, protein kinase $\mathrm{C}$; IEC-18, intestinal epithelial cells 18; Lop, loperamide; No, untreated; Veh, vehicle; AEtLP, aqueous extract of Liriope platyphylla; DG, diosgenin; 5-HMF, 5-hydroxymethylfurfural; AD, adenosine; HPC, hydroxypropyl cellulose; UD, uridine; PCP, prucalopride; BS, bisacodyl.

pRISMCs occurred in epithelial cells, the previous experiment was repeated in IEC-18 cells (Fig. 4A). Increased G $\alpha$ expression levels $(75 \%)$ were detected in the Lop+vehicle treatment group compared with the untreated group (Fig. 4B). In the Lop+AEtLP and Lop+PCP groups, this level increased by 12.6 and $8 \%$ compared with the Lop+vehicle treatment group. A significant decrease $(\mathrm{P}=0.042)$ was detected only following treatment with three (DG, 5-HMF and UD) out of the five candidates.

The phosphorylation levels of PKC differed from $\mathrm{G} \alpha$ expression levels (Fig. 4C). Phosphorylation levels increased $358 \%$ in the Lop+vehicle treatment group compared with the untreated group. However, Lop+AEtLP and Lop+BS treatment induced complete recovery of PKC phosphorylation levels, whereas Lop+PCP treatment induced a significant decrease of $56.4 \%(\mathrm{P}=0.016)$. Taken together, these results indicate that all five candidates may mimic the effects of AEtLP and BS in intestinal epithelial cells.
Effect of the five laxative candidates on the 5-HT receptor signaling pathway in neuronal cells. To determine whether the five laxative candidates affect the 5-HT receptor signaling pathway in neuronal cells, the expression levels of $\mathrm{G} \alpha$ and phosphorylation levels of PKC were measured in Lop-pretreated B35 cells following treatment with the five laxative candidates (Fig. 5A). The G $\alpha$ expression levels were reduced by $49 \%$ in the Lop+vehicle treatment group compared with the untreated group (Fig. 5B). These levels were further decreased by $83-95 \%$ in the Lop+AEtLP, Lop+PCP and Lop+BS positive control treatment groups. Following treatment with the five candidates, the expression levels of $\mathrm{G} \alpha$ increased in the Lop+5-HMF and Lop+HPC treatment groups compared with the Lop+vehicle treatment group. The $\mathrm{G} \alpha$ expression levels remained constant in the three remaining groups (DG, AD and UD). PKC phosphorylation levels did not correspond with $\mathrm{G} \alpha$ expression levels (Fig. 5C). Phosphorylation levels were not altered in the 

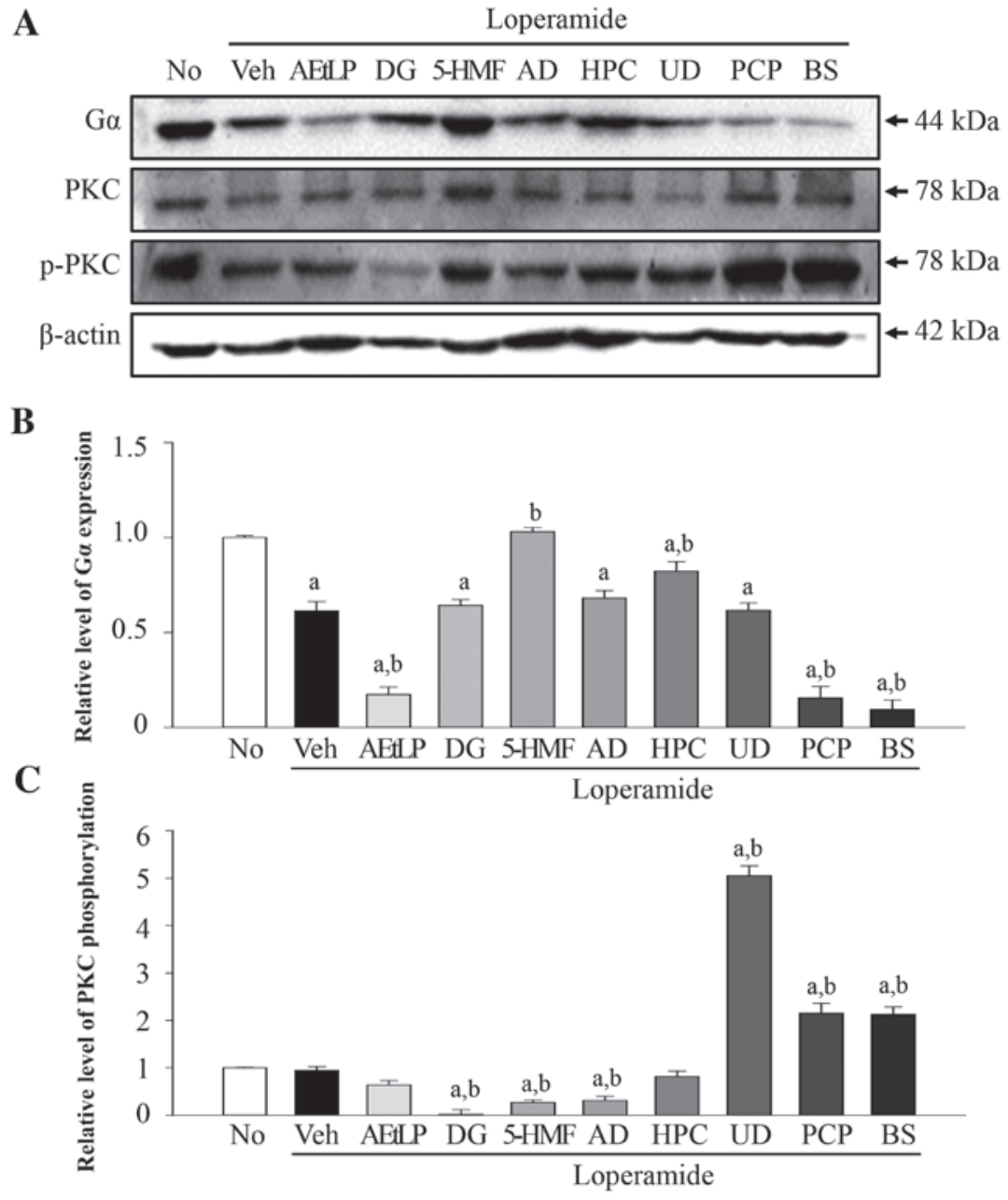

Figure 5. Alteration of G $\alpha$ expression and PKC phosphorylation levels in B35 cells. (A) Western blot analysis was performed on total protein extracted from the Lop-pretreated B35 cells following treatment with the five laxative candidates. The levels of Ga expression and PKC phosphorylation were detected with specific antibodies. The $\beta$-actin protein expression level served as an endogenous control. The band intensity of the three proteins was determined using densitometry and the level of (B) G $\alpha$ expression and (C) PKC phosphorylation was calculated relative to $\beta$-actin. Data are presented as the mean \pm standard deviation of three replicates. ${ }^{a} \mathrm{P}<0.05$ vs. untreated group; ${ }^{b} \mathrm{P}<0.05$ vs. Lop+vehicle treatment group. $\mathrm{G} \alpha, \mathrm{G}$ protein $\alpha$; PKC, protein kinase $\mathrm{C}$; Lop, loperamide; No, untreated; Veh, vehicle; AEtLP, aqueous extract of Liriope platyphylla; DG, diosgenin; 5-HMF, 5-hydroxymethylfurfural; AD, adenosine; HPC, hydroxypropyl cellulose; UD, uridine; PCP, prucalopride; BS, bisacodyl.

Lop+vehicle and Lop+AEtLP treatment groups; however, they were increased by $120 \%$ in the Lop+PCP and BS treatment groups. The Lop+UD treatment group also exhibited increased PKC phosphorylation levels; however, a significant decrease $(\mathrm{P}=0.032)$ was detected in the $\mathrm{DG}, 5-\mathrm{HMF}$ and $\mathrm{AD}$ treatment groups. Taken together, the above results indicated that only UD may mimic the effect of PCP and BS on PKC phosphorylation levels in B35 neuroblastoma cells.

Effects of the five laxative candidates on IP3 concentration.IP3 concentrations in pRISMCs, IEC-18 and B35 cells co-treated with Lop and the five candidates were examined to confirm the results of the 5-HT receptor signaling pathway analysis. Although IP3 was detected in pRISMCs, IEC-18 and B35 cells, a significant alteration $(\mathrm{P}=0.017)$ during Lop treatment was detected only in pRISMCs (Fig. 6A). IEC-18 (Fig. 6B) and B35 (Fig. 6C) cells did not exhibit any significant alterations $(\mathrm{P}=0.028)$ in IP3 concentrations. In pRISMCs, the relative levels of IP3 were decreased by $21 \%$ in the Lop+vehicle treatment group compared with the untreated group. However, these levels recovered following AEtLP, PCP and BS treatment. In addition, IP3 levels were increased in all five candidate-treated groups, although to a lesser extent than AEtLP and PCP. The greatest increase (223\%) was detected in the Lop+UD treatment group. These results demonstrate that UD induces a marked increase of IP3 concentration in smooth muscle cells.

Quantification of $A D$ and $U D$. UD was selected as the candidate with the greatest potential as a novel laxative based on the G $\alpha$ expression, PKC phosphorylation and IP3 concentration levels data; therefore, the concentration of UD was quantified. In addition, AD was quantified as a control. The linearity for AD and UD analysis was assessed using six standard solutions (each injected in triplicate) in a 0.5-50.0 $\mu \mathrm{g}$ $\mathrm{ml}^{-1}$ concentration range. The six-point calibration curves were observed to be linear as least squares regression gave a correlation coefficient of 0.9999 (Table II). LOD and LOQ were defined as a signal-to-noise ratio of 3 and 10, respectively; LOD ranged from 0.205 to $0.738 \mu \mathrm{g} \mathrm{ml}^{-1}$ and LOQ from 0.062 to $0.224 \mu \mathrm{g} \mathrm{ml}^{-1}$. Comparing retention times with 
Table II. Contents of AD and UD in roots sample of L. platyphylla.

\begin{tabular}{lcccccc}
\hline Compound & $\begin{array}{c}\text { Regression } \\
\text { equation }\end{array}$ & $\begin{array}{c}\text { Correlation } \\
\text { coefficient }\end{array}$ & $\begin{array}{c}\text { Linear range } \\
(\mu \mathrm{g} / \mathrm{l})\end{array}$ & $\begin{array}{c}\text { Limit of detection } \\
(\mu \mathrm{g} / \mathrm{l})\end{array}$ & $\begin{array}{c}\text { Limit of quantification } \\
(\mu \mathrm{g} / \mathrm{l})\end{array}$ & $\begin{array}{c}\text { Content } \\
(\mu \mathrm{g} / \mathrm{g} \text { dry weight })\end{array}$ \\
\hline $\mathrm{AD}$ & $\mathrm{y}=33.02 \mathrm{x}-2.35$ & 0.999994 & $0.5-50.0$ & 0.224 & 0.738 & $78 \pm 2$ \\
$\mathrm{UD}$ & $\mathrm{y}=23.79 \mathrm{x}+0.34$ & 0.999999 & $0.5-50.0$ & 0.062 & 0.205 & $172 \pm 2$ \\
\hline
\end{tabular}

$\mathrm{AD}$, adenosine; UD, uridine.

A

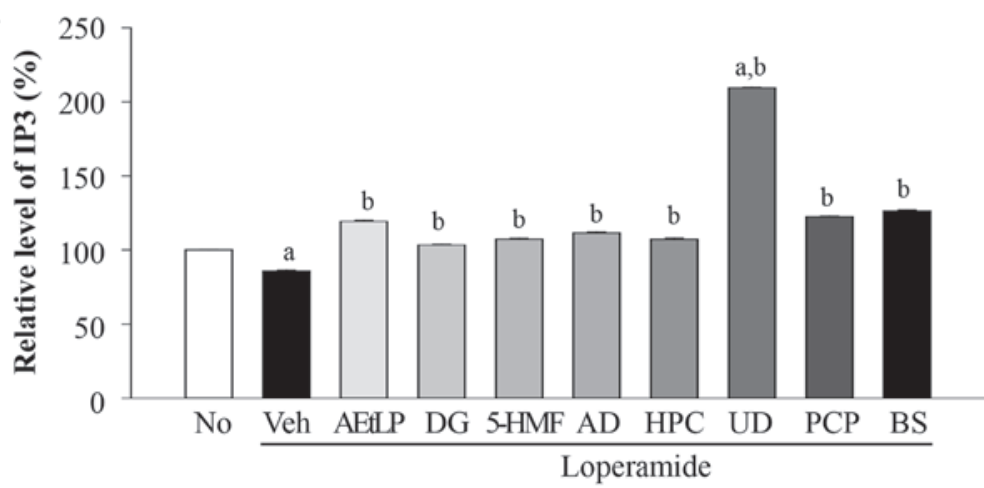

B

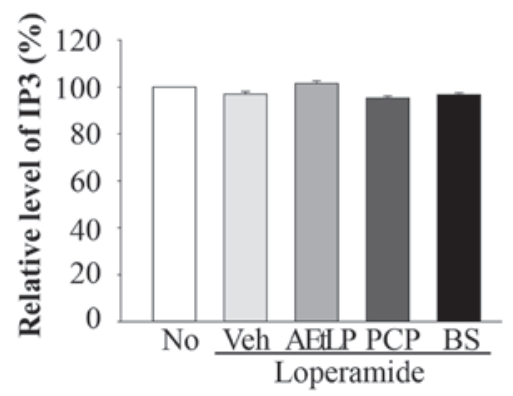

C

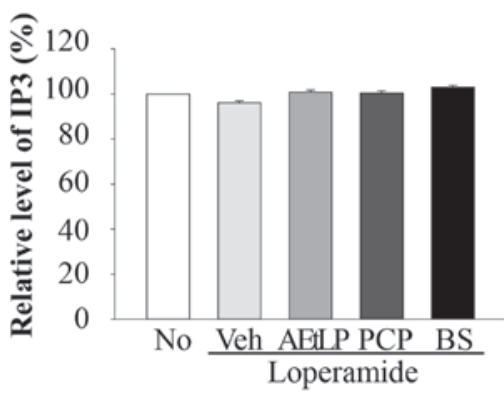

Figure 6. Alteration of IP3 concentration in pRISMCs, IEC-18 and B35 cells. Following treatment with Lop for $12 \mathrm{~h}$, the three cell types were incubated with the five candidates. The IP3 concentration in the total cell lysate of (A) pRISMCs, (B) IEC-18 and (C) B35 cells was measured using an enzyme-linked immunosorbent assay kit that detected 5 to $1000 \mathrm{pg} / \mathrm{ml}$ IP3. Data are presented as the mean \pm standard deviation of three replicates. ${ }^{\mathrm{a}} \mathrm{P}<0.05 \mathrm{vs}$. untreated group; ${ }^{\mathrm{b}} \mathrm{P}<0.05 \mathrm{vs}$. Lop+vehicle treatment group. IP3, inositol triphosphate; pRISMC, primary rat intestine smooth muscle cells; IEC-18, intestinal epithelial cells 18; Lop, loperamide; No, untreated; Veh, vehicle; AEtLP, aqueous extract of Liriope platyphylla; DG, diosgenin; 5-HMF, 5-hydroxymethylfurfural; AD, adenosine; HPC, hydroxypropyl cellulose; UD, uridine; PCP, prucalopride; BS, bisacodyl.

those of authentic standards, UD and AD were revealed to be 172 and $78 \mu \mathrm{g} / \mathrm{g}$ dry weight, respectively (Table II).

\section{Discussion}

Constipation is a heterogeneous disease associated with several symptoms, including infrequent bowel movements, difficult fecal passage and a sensation of incomplete defecation $(31,32)$. In accordance with an increase in the incidence of constipation, attempts have been made to identify novel drugs from various natural resources. In an effort to purify and examine novel drugs for the treatment of constipation, the effects of five laxative candidates originating from L. platyphylla were examined in three major cell types present in the transverse colon. The results of the present study demonstrated the potential of UD to mimic the effects of PCP and AEtLP in pRISMCs, ICE-180 and B35 cells, although animal studies are necessary to clarify the laxative effects on chronic constipation. The present study investigated G $\alpha$, PKC and IP3 within the downstream signaling pathway of the 5-HT receptor as their regulation may closely associate with movement through the gastrointestinal tract.

DG is a steroid sapogenin produced by saponin hydrolysis during treatment with acids, strong bases or enzymes (33). In addition, DG may be extracted from the tubers of Dioscorea esculenta,Angelica gigas and Trigonellafoenum-graecum(34), and exerts biological activity against various metabolic diseases, including dyslipidemia, obesity, diabetes, cholestasis and cancer $(33,35)$. A limited number of studies have been conducted to investigate the effects of $\mathrm{DG}$ on $\mathrm{PKC}$ activation in the 5-HT receptor signaling pathway; however, a previous study revealed significantly increased PKC phosphorylation induced by DG administration in type I diabetic rats (35). In the present study, the phosphorylation levels of PKC were 
decreased in smooth muscle cells, epithelial cells and neuronal cells following Lop + DG treatment. These differences may be due to various factors, including Lop cotreatment and experimental conditions.

Extracellular nucleotide triphosphates (NTPs), including adenosine triphosphate (ATP) and uridine triphosphate (UTP), regulate various physiological actions in numerous tissues and cell types (36). In the airways of the lung, these compounds activate $\mathrm{Cl}^{-}$secretion from cystic fibrosis (CF) and non-CF airway epithelia, and regulate goblet cell-mediated mucin release $(37,38)$. This process is mediated by $\mathrm{P} 2 \mathrm{Y}$ or $\mathrm{P} 2 \mathrm{U}$ receptors, which are $\mathrm{G}$ protein-coupled receptors that activate the phospholipase $\mathrm{C}$ (PLC) signaling cascade $(39,40)$. PLC results in calcium release, PKC activation and phosphatidylinositol 4,5-bisphosphate depletion through cleavage into diacylglycerol and IP3 (40). Although numerous studies have reported the function of extracellular NTPs as regulatory molecules, their role in the 5-HT receptor signaling pathway associated with constipation has not been investigated. However, it has previously been suggested that ATP and UTP are associated with the improvement of constipation since their activity stimulates mucin release from goblet cells (38). In the present study, AD in muscle cells and epithelial cells induced effects on PKC phosphorylation that mimicked PCP and BS, while UD was effective in epithelial cells and neuronal cells. These results provide the first evidence that AD and UD may improve Lop-induced constipation via regulation of the 5-HT receptor signaling pathway.

Of the various insoluble dietary fibers, including psyllium, glucomannan and chitosan, cellulose facilitates the movement of waste through the human digestive tract and prevents chronic constipation (41). Oral administration of $5 \mathrm{mg}$ /day cellulose significantly increased fecal excretion in Lop-induced constipated rats (41), whereas methylcellulose treatment increased the frequency of bowel movements and the ease of fecal passage (42). To the best of our knowledge, no studies have reported an association between HPC and chronic constipation, although it is widely used to treat insufficient tear production, and as food additives and disintegrants. In the present study, the effect of HPC treatment on Ga expression and PKC phosphorylation levels was examined in three cell types present in the transverse colon, and the results revealed that HPC mimicked the effect of AEtLP on G $\alpha$ expression in pRISMCs and IEC-18 as well as PKC phosphorylation in IEC-18 and B35 cells.

In conclusion, the present study investigated the effects of five laxative candidates derived from L. platyphylla on the 5-HT receptor signaling pathway to select a potential novel laxative. Laxative candidates were selected on the basis of reversing the effects of Lop and mimicking the activity of current therapeutic agents or AEtLP in at least two cell types. Analysis of the $\mathrm{G} \alpha$ expression levels in the three cell types revealed three laxative candidates (DG, 5-HMF and UD), whereas results from PKC phosphorylation in the three cell types suggested three laxative candidates (DG, AD and UD). The additional analysis of IP3 concentration indicated only one strong candidate (UD). Therefore, the results of the present study suggested that UD may be considered as a potential laxative in the treatment of chronic constipation, although it did not exactly mimic the effects of AEtLP, PCP and BS. Further studies are required to investigate the therapeutic effects of these laxatives in a Lop-induced constipation model based on the measurement of the number of feces, histological analysis and the expression of associated proteins.

\section{Acknowledgements}

The authors would like to thank Miss. Jin Hyang Hwang, the animal technician, for directing the Animal Facility and Care at the Laboratory Animal Resources Center of Pusan National University (Miryang, Korea), and Professor Byung Joo Kim (Pusan National University School of Korean Medicine, Yangsan, Korea) for technical support in the collection of primary smooth muscle cells from the rat intestines. The present study was supported by the Basic Science Research Program through the National Research Foundation of Korea funded by the Ministry of Education (grant no. 2014R1A1A2058360).

\section{References}

1. Young SN: How to increase serotonin in the human brain without drugs. J Psychiatry Neurosci 32: 394-399, 2007.

2. Ahn $J$ and Ehrenpreis ED: Emerging treatments for irritable bowel syndrome. Expert Opin pharmacother 3: 9-21, 2002

3. Bulbring E and Crema A: The release of 5-hydroxytryptamine in relation to pressure exerted on the intestinal mucosa. J Physiol 146: 18-28, 1959.

4. Gershon MD: Serotonin: Its role and receptors in enteric neurotransmission. Adv Exp Med Biol 294: 221-230, 1991.

5. Baker DE: Rationale for using serotonergic agents to treat irritable bowel syndrome. Am J Health Syst Pharm 62: 700-711; quiz 712-713, 2005.

6. Sikander A, Rana SV and Prasad KK: Role of serotonin in gastrointestinal motility and irritable bowel syndrome. Clin Chim Acta 403: 47-55, 2009.

7. Costedio MM, Hyman N and Mawe GM: Serotonin and its role in colonic function and in gastrointestinal disorders. Dis Colon Rectum 50: 376-388, 2007.

8. Crowell MD: Role of serotonin in the pathophysiology of the irritable bowel syndrome. Br J Pharmacol 141: 1285-1293, 2004.

9. El-Salhy M, Danielsson A, Stenling R and Grimelius L: Colonic endocrine cells in inflammatory bowel disease. J Intern Med 242: 413-419, 1997.

10. Lincoln J, Crowe R, Kamm MA, Burnstock G and Lennard-Jones JE: Serotonin and 5-hydroxyindol acetic acid are increased in the sigmoid colon in severe idiopathic constipation. Gastroenterol 98: 1219-1225, 1990.

11. Zhao R, Baig MK, Wexner SD, Chen W, Singh JJ, Nogueras JJ and Woodhouse S: Enterochromaffin and serotonin cells are abnormal for patients with colonic inertia. Dis Colon Rectum 43: 858-863, 2000.

12. Callahan MJ: Irritable bowel syndrome neuropharmacology. A review of approved and investigational compounds. J Clin Gastroenterol 35 (1 Suppl): S58-S67, 2002.

13. Kamm MA, Müller-Lissner S, Talley NJ, Tack J, Boeckxstaens G, Minushkin ON, Kalinin A, Dzieniszewski J, Haeck P, Fordham F, et al: Tegaserod for the treatment of chronic constipation: A randomized, double-blind, placebo-controlled multinational study. Am J Gastroenterol 100: 362-372, 2005.

14. von der Ohe MR, Hanson RB and Camilleri M: Serotonergic mediation of postprandial colonic tonic and phasic responses in humans. Gut 35: 536-541, 1994.

15. Kakino M, Izuta H, Ito T, Tsuruma K, Araki Y, Shimazawa M, Oyama M, Inuma M and Hara H: Agarwood induced laxative effects via acetylcholine receptors on loperamide-induced constipation in mice. Biosci Biotechnol Biochem 74: 1550-1555, 2010.

16. Lee HY, Kim JH, Jeung HW, Lee CU, Kim DS, Li B, Lee GH, Sung MS, Ha KC, Back HI, et al: Effects of Ficus carica paste on loperamide-induced constipation in rats. Food Chem Toxicol 50: 895-902, 2012. 
17. Méité S, Bahi C, Yéo D, Datté JY, Djaman JA and N'guessan DJ: Laxative activities of Mareya micrantha (Benth.) Müll. Arg. (Euphorbiaceae) leaf aqueous extract in rats. BMC Complement Altern Med 10: 7, 2010

18. Wintola OA, Sunmonu TO and Afolayan AJ: The effect of Aloe ferox Mill. in the treatmentet of loperamide-induced constipation in Wistar rats. BMC Gastroenterol 10: 95, 2010.

19. Kim JE, Lee YJ, Kwak MH, Ko J, Hong JT and Hwang DY: Aqueous extracts of Liriope platyphylla induced significant laxative effects on loperamide-induced constipation of SD rats. BMC Complement Altern Med 13: 333, 2013.

20. Kim BJ: Shengmaisan refulates pacemaker potentials in interstitial cells of cajal in mice. J Pharmacopuncture 16: 36-42, 2013.

21. Thyberg J, Hedin U, Sjölund M, Palmberg L and Bottger BA Regulation of differentiated properties and proliferation of arterial smooth muscle cells. Arteriosclerosis 10: 966-990, 1990.

22. Parajuli SP, Choi S, Lee J, Kim YD, Park CG, Kim MY, Kim HI Yeum CH and Jun JY: The inhibitory effects of hydrogen sulfide on pacemaker activity of interstitial cells of cajal from mouse small intestine. Korean J Physiol Pharmacol 14: 83-89, 2010.

23. Pari L, Monisha P and Mohamed Jalaludeen A: Beneficial role of diosgenin on oxidative stress in aorta of streptozotocin induced diabetic rats. Eur J Pharmacol 691: 143-150, 2012.

24. Huang $\mathrm{CH}, \mathrm{Ku} \mathrm{CY}$ and Jan TR: Diosgenin attenuates allergen-induced intestinal inflammation and IgE production in a murine model of food allergy. Planta Med 75: 1300-1305, 2009.

25. Yamada T, Hoshino M, Hayakawa T, Ohhara H, Yamada $H$ Nakazawa T, Inagaki T, Iida M, Ogasawara T, Uchida A, et al: Dietary diosgenin attenuates subacute intestinal inflammation associated with indomethacin in rats. Am J Physiol 273: G355-G364, 1997.

26. Black CT, Hennessey PJ, Ford EG and Andrassy RJ: Protein glyosylation and collagen metabolism in normal and diabetic rats. J Surg Res 47: 200-202, 1989.

27. Nicolau CT, Teitel P, Bratu V, Xenakis A and Butoianu E: Favorable therapeutic effect of adenosine monophosphate (AMP) in a case of compensated chronic hemolytic disease due to insufficiency of erythrocytic energetic metabolism. Med Interna (Bucur) 17: 423-430, 1965 (In Romanian).

28. Tsukamoto H: Extracellular adenosine is a therapeutic target for limiting graft-versus-host disease and enhancing the graft-versus-tumor effect against hematopoietic malignancy. Yakugaku Zasshi 134: 1021-1027, 2014 (In Japanese).

29. Krishnaiah YS, Kumar MS, Raju V, Lakshmi M and Rama B Penetration-enhancing effect of ethanolic solution of menthol on transdermal permeation of ondansetron hydrochloride across rat epidermis. Drug Deliv 15: 227-234, 2008.
30. Oswald S, Giessmann T, Luetjohann D, Wegner D, Rosskopf D, Weitschies W and Siegmund W: Disposition and sterol-lowering effect of ezetimibe are influenced by single-dose coadministration of rifampin, an inhibitor of multidrug transport proteins. Clin Pharmacol Ther 80: 477-485, 2006.

31. Herz MJ, Kahan E, Zalevski S, Aframian R, Kuznitz D and Reichman S: Constipation: A different entity for patients and doctors. Fam Pract 13: 156-159, 1996.

32. Thompson WG, Longstreth GF, Drossman DA, Heaton KW, Irvine EJ and Müller-Lissner SA: Functional bowel disorders and functional abdominal pain. Gut 45 (Suppl 2): II43-II47, 1999.

33. Raju J and Rao CV: Diosgenin, a steroid saponin constituent of Yams and Fenugreek: Emerging evidence for applications in medicine. In: Bioactive Compounds in Phytomedicine. Rasooli I (ed). InTech, Rijeka, pp125-142, 2012.

34. Taylor WG, Elder JL, Chang PR and Richards KW: Microdetermination of diosgenin from fenugreek (Trigonella foenum-graecum) seeds. J Agric Food Chem 48: 5206-5210, 2000 .

35. Sato K, Fujita S and Iemitsu M: Acute administration of diosgenin or dioscorea improves hyperglycemia with increases muscular steroidogenesis in STZ-induced type 1 diabetic rats. J Steroid Biochem Mol Biol 143: 152-159, 2014

36. Barke AJ and Julius D: Signaling by extracellular nucleotides. Annu Rev Cell Dev Biol 12: 519-541, 1996.

37. Knowler MR, Clarke LL and Boucher RC: Activation by extracellular nucleotides of chloride secretion in the airway epithelia of patients with cystic fibrosis. N Engl J Med 325: $533-538,1991$

38. Lethem MI, Dowell ML, Van Scott M, Yankaskas JR, Egan T, Boucher RC and Davis CW: Nucleotide regulation of goblet cells in human airway epithelial explants: Normal exocytosis in cystic fibrosis. Am J Respir Cell Mol Biol 9: 315-322, 1993.

39. Ralevic V and Burnstock G: Receptors for purines and pyrimidines. Pharmacol Rev 50: 413-492, 1998.

40. Falkengurger BH, Dickson EJ and Hille B: Quantitative properties and receptor reserve of the DAG and PKC branch of G(q)-coupled receptor signaling. J Gen Physiol 141: 537-555, 2013.

41. Shimotoyodome A, Meguro S, Hase T, Tokimitsu I and Sakata T: Sulfated polysaccharides, but not cellulose, increase colonic mucus in rats with loperamide-induce constipation. Dig Dis Sci 46: 1482-1489, 2001

42. Snape WJ Jr: The effect of methylcellulose on symptoms of constipation. Clin Ther 11: 572-579, 1989. 